\title{
THE GOLDEN STANDARD OF CONCEPTS WITH NECESSARY CONDITIONS AND THE CONCEPT OF LAW
}

\author{
Enrique CÁCERES NIETO
}

Resumen:

En este artículo contiendo la tesis defendida por Michael Giudice en la cual sostiene que es posible elaborar un concepto de derecho mediante la determinación de las propiedades necesarias de su esencia. Mis tesis principales son: 1) que sólo para cierto tipo de conceptos puede alcanzarse ese objetivo y 2) que el concepto de "Derecho" no es uno de ellos. Defiendo un pluralismo metodológico contra el monismo metodológico suscrito por algunos filósofos del derecho contemporáneos.

Palabras clave:

El estándar dorado de los conceptos, metodología jurídica, análisis conceptual, pluralismo conceptual, monismo conceptual, propiedades esenciales del derecho.

\section{Abstract:}

In this paper I argue against the thesis defended by Michael Giudice, who claims that it is possible to provide a concept of law by determining the necessary conditions of its essence. My main thesis is: 1) that this goal can exclusively be reached with certain kind of concepts: those satisfying what I propose to call: "Golden Standard of Concepts with Necessary Conditions" and 2) that the concept of "Law" is not such a concept. Therefore I defend 


\section{ENRIQUE CÁCERES NIETO}

methodological pluralism in opposition to methodological monism embraced by some contemporary legal philosophers.

Keywords:

The Golden Standard of Concepts, Legal Methodology, Conceptual Analysis, Conceptual Pluralism, Conceptual Monism, Essential Properties of Law. 
Summary: I. Introduction. II. Pseudo-Problems. III. The Essence or Nature of Law as an Object of Analytical Jurisprudence. IV. Conceptual Analysis Contenders. V. The Replies. VI. About the Naturalization of Legal Philosophy.

\section{INTRODUCTION}

Let me begin with a brief reference to the history of philosophy. Back in the 7th century B.C., when mythology was the one and only way of explaining natural phenomena, the Greek philosopher Thales of Miletus approached nature in a quite new fashion. While others appealed to Gods for accounting natural phenomena, Thales exposed his geometry through concepts like:

"If $\mathrm{A}, \mathrm{B}$ and $\mathrm{C}$ are points on a circle where the line $\mathrm{AC}$ is a diameter of the circle, then the angle $\mathrm{ABC}$ is a right angle».

Or:

"A triangle is a three-sided polygon whose interior angles add up to $180^{\circ}$ ". ${ }^{1}$

These geometric concepts are very useful to the purpose of this comment, for they satisfy what I propose to denote with the expression "The golden standard of concepts with necessary conditions". The features of this standard are:

1) Conceptual monism: there is no room for alternative concepts to the same object. Although it might be possible to define a triangle with other words, the concept would finally be the same.

2) Invariantism: the concept is free from context dependence, or, in other words, it doesn't change in different contexts or times

1 Health, Thomas Little Sir, A History of Greek Mathematics: From Thales to Euclid, Vol. I, USA/Oxford, The Clarendon Press, 2000, p. 131. 
3) Exhaustibility: the concept includes all instances of the same kind without exceptions. All types of triangles are included in the definition.

4) Indefeasiblility: the concept cannot be defeated by counter- examples.

5) a priori-ness: the concept is not a result of social agreement or empirical data.

A different and more philosophical way for characterizing a concept that satisfies the golden standard is the following - using the language of possible worlds-:

A property $P$ or set of properties $P$-s is (are) an essential property of an object $O$, if and only if, in all possible worlds $O$ has $P$.

Or, through an existence-conditioned modal characterization:

$A P$ or set of $P$-s is or are essential properties of an object $O$, if and only if, it is necessary that $O$ has $P$ if $O$ exists.

As we have seen, there is at least one kind of object that satisfies the golden standard: geometric concepts. However, this doesn't imply that for every $x$, if $x$ is a concept, then $x$ satisfies the golden standard. For the contrary, I assume the existence of at least one possible $x$ which is a concept and doesn't satisfy the golden standard. Thus, the philosophical task of analyzing concepts will be successful as long as we are concerned with the kind of concepts that satisfies the golden standard (CSGS).

\section{PsEudo-PRoBlems}

By the term 'pseudo-problem' let me stipulate the following meaning: It is an apparent problem which is not really a problem, for the way in which it is exposed warrants the impossibility of its solution: for instance, when somebody is asked to draw a square circle. 
The considerations mentioned above are relevant here because I assume that if necessary conditions of a concept -or its essence- don't satisfy the golden standard requirements, that concept can be considered as a pseudo-problem.

Similarly, I want to raise a question as to whether or not the concept of law is an instance of the kind of concepts that satisfy the golden standard, and therefore whether or not the goal of finding the essence of the concept of law can be achieved.

III. THE EsSENCE OR NATURE OF LAW AS AN OBJECT OF ANALYTICAL JURISPRUDENCE

Julie Dickson claims that:

Analytical jurisprudence is concerned with explaining the nature of law by attempting to isolate and explain those features which make law into what it is. A successful theory of law of this type is a theory which consists of propositions about the law which (1) are necessarily true, and (2) adequately explain the nature of law. ${ }^{2}$

In my interpretation, this means that analytical jurisprudence approaches the law by means of a concept of the kind of CSGS, and therefore its purpose is to provide that concept.

\section{Conceptual Analysis Contenders}

a) The Pluralist

It seems to me that the above interpretation about the goal of analytical jurisprudence is challenged by the plural-

2 Dickson, Julie, Evaluation and Legal Theory, Oxford, Hart Publishing, 2001, p. 17. 
ist. A pluralistic criticism is frequently tended to show that the concept of law fails in meeting the following properties of CSGS:

1) Conceptual monism

2) Invariantism

3) Exhaustive coverage of the concept

The strategy against 1) and 2) is to present counter-examples of different concepts of law, and against 3) to claim that the definition of law linked to the concept of state is just one concept of law among others. Then, for pluralist critics - different from CSGS- the properties involved in the definition of the concept of law are:

1) Conceptual pluralism (in opposition to conceptual monism)

2) Context dependence (in opposition to invariantism)

3) Non-exhaustive epistemic coverage

Therefore this pluralistic view rejects "conceptual imperialism" that lies behind analytical jurisprudence, as well as the idea that the concept of law is necessarily linked to the concept of state. In other terms: to the pluralist there is at least one $x$, which is a concept of law, and is not linked to the concept of state.

\section{b) Self-Understanding and Irresolvable Boundary Disputes}

To my view, the thesis presented by philosophers such as Dan Priel is grounded in the properties of conceptual pluralism, contextualism and non exhaustive coverage in legal theory. I would call the thesis argued by these authors as the "incommensurability thesis in legal theory".

Two important comments on Priel's claims need to be made: Firstly, he accepts conceptual analysis as a valid method in obtaining diverse concepts of law. That means that even if he is a conceptual pluralist he might be consid- 
ered as a methodological monist. A second point in this kind of skepticism, as opposed to the fifth property of CSGS, consists in denying the possibility of a priori concepts of law.

\section{THE REPLIES}

a) A Response to the Thesis of the Non-Exhaustive Coverage of Analytical Jurisprudence

In response to the non-exhaustive coverage of analytical legal theories and conceptual imperialism, Michael Giudice affirms:

Analytical legal theorists can scarcely be faulted for incorrectly explaining non-state forms of law when they have explicitly limited their theories to law in its state form. The problem is one of oversight or ignorance, not mistake. ${ }^{3}$

I think this is probably not the best possible counter-argument against Tamanaha, given that the goal of analytical jurisprudence - as Julie Dickson argues - is not the concept of state law, but the nature of law in general.

b) A Response to the Critic against Necessary Features of Concepts of Law and the Essential Properties of Law

I found this part of the paper very interesting because the alleged opposition between analytical legal philosophers and their (pluralist) contenders seems to disappear.

According to Giudice, Joseph Raz, who is one of the most important advocates of analytical jurisprudence, explicitly subscribes some of the theses put forward by his opponents:

3 Giudice, Michael, "Conceptual Analysis and Its Critics", Problema. Anuario de Filosofía y Teoría del Derecho, No. 6, 2012, p. 17. 
ENRIQUE CÁCERES NIETO

1) Conceptual pluralism, in terms of Raz (quoted by Giudice):

There is no uniquely correct explanation of a concept, nothing which could qualify as the explanation of the concept of law. There can be a large number of correct alternative explanations of a concept...4

2) Contextualism: Not all will be equally appropriate for all occasions. Appropriateness is a matter of relevance to the interests of the expected or intended public, appropriateness to the questions which trouble it, to the puzzles which confuse it... The relativity of good explanations to the interests and the capacities of their public make them ephemeral and this explains why philosophy has a neverending task

3) Not-a priori nature of concepts

"A central aim of philosophy of law -Giudice continues his explanation of Raz- [...] is to offer explanations of the general concepts of law (and the concept of law itself) which are responsive to both citizens' and theorists' interests in a way which illuminates their self-understanding". ${ }^{5}$ By inference we can assume that Raz holds the thesis of the defeasibility of legal theories in opposition to the un-defeasibility of CSGS. There is nothing in Raz's thoughts about the incommensurability thesis.

Until now it seems to me that there are some important conclusions that should be highlighted. Against the interpretation of the goal of analytical jurisprudence as providing THE concept of Law which must satisfy the golden standard, Raz and the contenders agree on the impossibility of achieving this goal. Both hold at least conceptual pluralism in opposition to conceptual monism, contextualism in op-

4 Ibidem, p. 19.

5 Ibidem, p. 20. 
position to invariantism, not exhaustive coverage of any legal theory, and not a priori nature of the concepts of law.

On the other hand, contenders hold the thesis that conceptual analysis plays a very important role in the analysis of social practices and diverse concepts of Law.

But the agreement is only apparent. In Giudice's words:

...responsiveness to contingent practices and shifting interests might suggest that Raz's view is incapable of offering what a theory of law should: an explanation of law's universal and essential properties. But here appearances of having abandoned legal theory's goal are deceiving, and show a further way in which Raz's view of the methodology of legal theory is nuanced. The fact that explanations of the concept of law are explanations in service of particular inquirers' interests does not preclude holding at the same time that law has universal or essential properties. ${ }^{6}$

In order to understand this complex view we need to observe a distinction drawn by Raz between the nature of law and the concept of law (a distinction that earlier theorists, including Hart, failed to notice). The nature of law is a metaphysical object:

The appropriateness, aptness, or success of explanations presupposes their truth... It is important to emphasize that there is nothing in the relativity of good explanations to their public to threaten the non relativity of their truth. ${ }^{7}$

Hence, Giudice claims:

The nature of law is to be a metaphysical object having universal and essential properties, while the concept of law is a parochial, typically prevailing understanding of law's nature. ${ }^{8}$

6 Ibidem, p. 21.

7 Ibidem, at footnote 36, quoted by Giudice.

8 Ibidem, p. 22. 
Here I can only ask how Giudice justifies his claim that "what a theory of law should" is an explanation of universal and essential properties of law, despite the difficulties this kind of goal involves. Regarding Raz' thoughts I cannot understand what would be the epistemic advantages of introducing a metaphysical entity in which truth need to be "assumed". This entity is not a product of rationality, but dogmatic acceptance. Or in Giudice's words something that "is inaccessible to us".

Is it possible to base the program of analytical jurisprudence on something without epistemic support?

In a different part of his paper, Giudice claims that:

It is important to note that by this distinction Raz does not aim to argue that law really does have universal and essential properties -only that those committed to supposing that there is such a thing as the nature of law are committed to viewing law as having universal and essential properties. ${ }^{9}$

According to this quotation, it seems that the assumption of the nature of Law is that it has a regulatory ideal. But even in this case the introduction of metaphysical entities is unnecessary because it could be enough to affirm that the goal of jurisprudence is to provide concepts of Law with the most possible epistemic coverage considering the proposal of other legal theories. This strategy could be consistent with the refusal of conceptual monism. It is as if Raz said: "Ok, I agree with conceptual pluralism, but I need to save the conceptual imperialism of analytical jurisprudence by inventing that there is a kind of metaphysical monism without epistemic justification that must orient the admitted conceptual pluralism in analytical philosophy".

Probably earlier theorists, including Hart, failed to notice the distinction between concepts and a supposed nature of Law. Probably they did not think about this because they would have considered it to be irrational.

9 Idem. 


\section{About the Naturalization of Legal Philosophy}

Leiter's Considerations regarding the Golden Standard on the Denial of the a priori Thesis

According to Brian Leiter, who follows Quine, there are no analytical or necessary truths, and therefore if the goal of conceptual analysis is to provide necessary true conditions for the concept of Law, it is condemned to failure.

I strongly agree with Giudice when he affirms that there is much more to be naturalized than the problems of adjudication. For instance, our explanations about the way in which people organize and share concepts, and scholars construct theories (and then, legal concepts and legal theories) could be naturalized in continuity with the results provided by contemporary cognitive sciences.

As for the relation between legal theory and the empirical world, conceptual legal theories can be considered as the initial conceptual constructs which characterizes the beginning of every empirical research. For instance the statement that officials identify the rules of a system because they accept the same rule of recognition could be redefined in empirical terms as: is it true that officials share that belief? Is it true that their cognitive processes are only recognizing or otherwise constructing norms from diverse material which involve more than what has been produced by legal institutions? What could be the variables, and methods to measure the responses?

This is not the place to extend my considerations about the kind of research in which I am currently working on (which I propose to call "Legal Constructivism") but I can say that my target is to study legal and theoretical problems according to the results of cognitive sciences. From this approach there are good reasons to support the thesis defended by the contenders about conceptual pluralism, since the construction of concepts, as a part of social representations, emerge from self-organizing processes of social 
interactivity which explains the plurality of conceptions about the Law. But the same phenomena occur with theoretical concepts which are the product of a social epistemology that emerge at the interior of scientific or philosophical communities. When these cognitive processes achieve a stable state then a concept has emerged.

I agree with Giudice and Hart about the underdeveloped situation of social and psychological sciences in the 60's. But things have changed and nowadays it is not necessary to return to the epistemic habits common before Thales of Miletus, and neither is it necessary to explain the world in terms of metaphysical entities as in the Razian idea of the "nature of law". 